\title{
Duhovnost kao resurs snage i otpornosti obitelji u rizičnim okolnostima
}

Ivan Leutar*

UDK: 249

ileutar@vodafone.de

248:316.356.2

Zdravka Leutar***

Izvorni znanstveni rad / Original scientific paper

Primljeno: 2. studenog 2016.

zleutar@pravo.hr

Prihvaćeno: 30. prosinca 2016.

Duhovnost se može shvatiti kao ljudsku potrebu za pronalaženjem krajnjeg smisla $i$ svrhe u životu te želju da se živi integriranim životom. Istraživanja su pokazala da religiozne obitelji, $u$ odnosu na one koje to nisu, za vrijeme trajanja nesigurnosti, neizvjesnosti $i$ stresa imaju veću razinu vjere $i$ nade u dobar ishod, njihovi članovi rjeđe izražavaju određene sociopatološke pojave. Cilj je rada dobiti uvid kako sudionici doživljavaju duhovnost u suočavanju s rizičnim okolnostima u obitelji, a istraživačko pitanje je: Kakvo je iskustvo sudionika koji prakticiraju duhovni život o ulozi duhovnosti u suočavanju s rizicima u obitelji? Sudionici su osobe kojima je duhovnost važna u životu i iz nje crpe snagu za životne izazove. Sudjelovalo je 12 osoba, oba spola, u dobi od 33 do 57 godina te su svi imali visoku stručnu spremu. U prikupljanju podataka koristio se kvalitativni pristup i metoda polustrukturiranog intervjua. Za analizu podataka korištena je tematska analiza. Dobiveni su sljedeći rezultati: duhovnost je mogući resurs osnaživanja članova obitelji u svim obiteljskim rizicima; duhovnost kao izvor snage moguća kod spoznaje vjere, nade i ljubavi kao istinskih životnih vrijednost; duhovne prakse - kao što su molitva, Božja riječ i sakramenti - osobiti su resursi u nošenju s teškim obiteljskim situacijama; zajedništvo, permanentna edukacija u duhovnosti i trajno obnavljanje u duhovnosti; važnost autentičnog življenja duhovnosti koja se očituje u konkretnim djelima u obitelji i okolini. Krize koje nastaju u duhovnom životu povezane su s krizama vjere i identiteta te postaju sredstva jačanja i transformacije same osobe i ćlanova obitelji. Za korištenje duhovnosti kao resursa otpornosti su važne predispozicije odgoja u vjeri i njegovanja duhovnosti članova od najranije dobi, ali se također spoznalo

\footnotetext{
* Doc. dr. sc. Ivan Leutar, docent na Filozofskom fakultetu Sveučilišta u Mostaru, Matice hrvatske bb, 88000 Mostar, Bosna i Hercegovina.

** Prof. dr. sc. Zdravka Leutar, redovita profesorica na Studijskom centru socijalnog rada Pravnog fakulteta Sveučilišta u Zagrebu, Nazorova 51, HR-10000 Zagreb.
} 
da duhovnost može biti otkrivena kao resurs upravo kroz krizu i da ona može biti sredstvo transformacije života obitelji.

Ključne riječi: duhovnost, obiteljska otpornost, obitelj u riziku, izvori snage, dobrobit duhovnosti, autentičnost, kriza vjere i identiteta, vjera, nada i ljubav.

\section{Uvod}

Tema duhovnosti se posljednjih desetljeća sve više stavlja u središte interesa brojnih istraživača. Nemali broj pojedinaca u potrazi je za autentičnim oblicima religioznosti u skladu s vremenom u kojemu žive i problemima s kojima se svakodnevno susreću. Duhovnost obuhvaća teme do kojih je svima stalo: o svrsi i smislu života, o miru, zdravlju, sreći, ljubavi, o životu i smrti. Buđenje duhovnosti stoga nije tek prolazna pojava, već nedvojbeno znak vremena u kojemu živimo. ${ }^{1}$ Autori se slažu da je duhovnost vrlo složen dio ljudskog iskustva te da kao takav ima kognitivne, iskustvene te ponašajne aspekte. ${ }^{2}$

Kognitivni aspekt odnosi se na potragu za smislom, svrhom, istinom, uvjerenjima, vrijednostima koje pojedinac živi; iskustveni aspekt odnosi se na osjećaj nade, ljubavi, mira, utjehe i podrške te ponašajni aspekt koji je manifestacija pojedinačnih duhovnih uvjerenja i unutarnjeg duhovnog stanja u svakodnevnom životu. Feldmeier ${ }^{3}$ iznosi svoje mišljenje o tome da svi mi imamo svoje ideje o tome tko je Bog, iako često toga nismo svjesni. On objašnjava da je isto i s duhovnošću jer svatko od nas ima svoje ideje o tome što naš život čini smislenim. »Duhovnost « dolazi od latinske riječi spiritus što znači »dah«, »disanje«. Bilo je mnogo nepodudarnosti u uspostavi formalne definicije duhovnosti zbog toga što se pojmovi duhovnost, vjera, i religija često koriste kao sinonimi, iako se vrlo malen broj znanstvenika s time slaže. ${ }^{4}$

Dakle, duhovnost se odnosi na područje ljudske egzistencije, koja leži u onostranosti svih materija, odnosno oblika, koji daju vlastitom životu osjećaj smislenosti, povezanosti, integriteta i nade. Za razliku od pojma religije, kod kojega je riječ o znanju, učenju ili o metodici spiritualnosti, ovdje se misli na stvarnu praksu. ${ }^{5} \mathrm{Na}$ taj način duhovnost u sebi sadrži i religioznost, a oni koji

${ }^{1}$ Usp. Anđelko DOMAZET, Kršćanska duhovnost u ozračju pluralizma, Crkva u svijetu, 38 (2003) 1, 41-73.

${ }^{2}$ Usp. Gowri ANANDARAJAH, Ellen HIGHT, Spirituality and medical practice. Using the hope questions as a practical tool for spiritual assessment, American Family Physician, 63 (2001) 1, 81-89.

${ }^{3}$ Usp. Peter FELDMEIER, What is spirituality?, U.S. Chatolic, 81 (2016) 15, 20-24.

${ }^{4}$ Usp. Margaret A. SCHNEIDER, Roger C. MANNELL, Beacon in the storm. An exploration of the spirituality and faith of parents whose children have cancer. Issues in Comprehensive Pediatric Nursing, 29 (2006) 1, 3-24.

${ }^{5}$ Usp. Zdravka LEUTAR, Ivan LEUTAR, Religioznost i duhovnost u socijalnom radu, Crkva u svijetu, 45 (2010) 1, 78-103. 
formalno ne pripadaju nijednoj religiji, ipak imaju duhovne potrebe jer su to potrebe koje svako ljudsko biće ima, kao npr. želja za smislom u životu.

Duhovnost u širem smislu možemo definirati kao oznaku duhovne dimenzije čovjeka, za razliku od njegove tjelesne i psihičke dimenzije, dok je ona $u$ užem smislu aktivnost kojom se razvija duhovna sposobnost čovjeka. ${ }^{6}$ Jedno od najnovijih istraživanja ${ }^{7}$ o poimanju duhovnosti navodi dobivene rezultate koji su razvrstani u nekoliko kategorija duhovnosti - duboka psihička svijest, trenuci osvjetljenja, otkrivanje novih dimenzija koje nas nadilaze, susret sa silama izvan racionalnog razumijevanja, izmijenjeno stanje svijesti, iskustvo strahopoštovanja, čudo, čežnja za povezivanjem, prisutnost nade, toplina osobnosti, ljubav, smisao života, potraga za smislom, putovanje u nepoznatom prav$\mathrm{cu}$, osjećaj cjeline, potraga za apsolutnom istinom, osjetljivost na druge osobe, energija, prepoznavanje granica čovjeka, molitva, meditacija, čitanje svetoga teksta. Schneider i Mannell objašnjavaju da su nada i duhovnost dva koncepta koja su beskrajno povezana i koja se često njeguju kada se pojedinci nalaze u nekom teškom životnom razdoblju, primjerice, kada se suočavaju s bolešću. ${ }^{8}$

U kršćanskoj literaturi koncept kršćanske duhovnosti promatramo kroz život vjernika te je duhovnost djelovanje Duha Svetoga, život s Bogom koji se postupno, uz njegovu milost, produbljuje te u tom kontekstu osvjetljava i naš odnos prema bližnjemu i prema svemu stvorenom. ${ }^{9} \mathrm{Na}$ taj način duhovnost označava sve ono što se tiče Božjega života u čovjeku i u njegovoj duši. Drugim riječima, kršćanska duhovnost artikulira se u događajima, u različitim oblicima i formama. Varijante su uvjetovane kroz vremenske prilike, životne oblike kao i kroz individualnost pojedinca. ${ }^{10}$ Tako Domazet navodi da inkulturacija kršćanske duhovnosti u današnjem kulturnom kontekstu je moguća kroz tri oblika: izgradnju kontemplativne osobnosti, teologiju drugoga i radost. ${ }^{11} \mathrm{~A}$ Mamić u svom teološkom promišljanju duhovnosti za naše vrijeme promatra kršćansku duhovnost kao povratak izvorima i dijalog sa suvremenim svijetom. ${ }^{12}$ On to vidi kao novu kategoriju unutar kršćanske duhovnosti koja bi trebala hraniti vjeru: kategorija povijesnosti, subjektnosti i svjetovnosti.

\footnotetext{
${ }^{6}$ Usp. Zdravka LEUTAR, Ivan LEUTAR, Josip TURČINOVIĆ, Iskustvo socijalnih radnika o duhovnosti u socijalnom radu, Ljetopis socijalnog rada, 20 (2013) 2, 215-239.

7 Alistair ROSS, Alistair Ross explores how counsellors can work with religion and spirituality in the therapy room, Spirituality in therapy, 27 (2016) 4, 22-25.

${ }^{8}$ Usp. Schneider, Mannell, nav. dj.

9 Atanazije J. MATANIĆ, Uvod u duhovnost, Zagreb, Kršćanska sadašnjost, 1994; 13-57; Michael PATTING, Was ist Spiritualität?, u: Mariana LEWKOWICZ, Andreas LOB-HÜDEPOHL, Spiritualität in der sozialen Arbeit, Freiburg i. Breisgau, 2003, 12-32; Milan ŠPEHAR, U potrazi za duhovnim iskustvom, Zagreb, Glas Koncila, 2004, 156-165; Josef WEISMAYER, Leben aus dem Geist Jesu. Grundzüge christlicher Spiritualität, Kevelaer, Topos, 2007, 16-31.

${ }^{10}$ Usp. Leutar, Leutar, nav. dj.

${ }^{11}$ Anđelko DOMAZET, Budućnost duhovnosti i nova religijska svijest, Služba Božja - liturgijskopastoralna revija, 46 (2006) 3, 271-293.

${ }^{12}$ Jakov MAMIĆ, Teološko promišljanje duhovnosti za naše vrijeme, Bogoslovska smotra, 73 (2003) 4, 777-794.
} 
U ovom radu promatrat ćemo duhovnost u kontekstu otpornosti i snage članova obitelji u riziku i pozabavit ćemo se nekim dosadašnjim istraživanjima na ovu temu. ${ }^{13}$ Istraživanja nesporno objašnjavaju pozitivnu korelaciju između duhovnosti i kvalitete života. ${ }^{14}$ Kao ilustraciju navodimo istraživanje na uzorku od 50 španjolskih obitelji u kojem su istraživali kvalitetu života i duhovnost, a dobiveni rezultati utvrdili su pozitivne korelacije navedenih konstrukata. ${ }^{15}$ Također, obitelji su navele da im je vjera iznimno važna te da ih ona vodi $k$ prihvaćanju invaliditeta, a posebice ako im nastanak invaliditeta ne može biti objašnjen od strane stručnjaka. Također, prema rezultatima kvalitativnog istraživanja na uzorku od 50 roditelja iz SAD-a, dobiveni rezultati govore o postojanju povezanosti između kvalitete života i prakticiranja duhovnosti. ${ }^{16}$ Navode da prakticiranje duhovnosti - odlaskom na molitve, privatne i organizirane; uključenošću u programe koje za njih organizira Crkva te aktivnim življenjem vjere - doprinosi ukupnosti kvalitete života pojedinca. Također, vjera daje smisao njihovu životu te putem vjere i odnosa s Bogom aktivno traže odgovore na osnovna životna pitanja. Nadalje, prema spomenutom istraživanju Younga koje je provedeno na 103 ispitanika, također je dobivena povezanost između kvalitete života i religijske aktivnosti, kao što su uključenost u Crkvu, razgovor o duhovnim stvarima te utjecaj duhovnog na svakodnevni život. ${ }^{17}$

Osobe koje prihvaćaju svoju vjersku pripadnost, te prakticiraju izraženu duhovnost, ujedno posjeduju i snažan resurs koji je posebno izražen u kriznim razdobljima života. ${ }^{18}$ Duhovnost i religioznost mogu biti velika blagodat upravo kod suočavanja s različitim vrstama stresora jer pridonose dobrobiti osobe, osiguravaju društvenu podršku, utječu na ukupnu kvalitetu života, propitkuju te traže različite odgovore i mehanizme rješenja te na taj način ubrzavaju kognitivni razvoj osobe jer djeluju proaktivno, a ne pasivizirajuće, te u konačnici jačaju proces samoaktualizacije, što je vrlo važan faktor u razvoju svake individue. ${ }^{19}$ Koliko duhovnost i religioznost mogu imati utjecaja i pozitivne implikacije $u$ svakodnevnim životnim teškoćama, govori nam pojam vjerskog suočavanja ${ }^{20}$

\footnotetext{
${ }^{13}$ Usp. Adina KARNER-HUTULEAC, Quality of life and spirituality, European Journal of Science and Theology, 8 (2012) 3, 135-141.

${ }^{14}$ Usp. Kim Wan YOUNG, Positive effects of Spirituality on Quality of life for people with severe Mental Ilness, International Journal of Psyhosocial Rehabilitation, 16 (2012) 2, 62-77.

${ }^{15}$ Usp. Denise J. POSTON, Ann P. TURNBULL, Role of spiritually and religion in Family Quality of Life for Families of Children with Disabilities, Education and Training in Developmental Disabilities, 39 (2004) 2, 95-108.

${ }^{16}$ Usp. Poston, Turnbull, nav. dj., 95-108.

${ }^{17}$ Usp. Young, nav. dj., 62-77.

${ }^{18}$ Usp. Anita DUČKIĆ, Slavica BLAŽEKA KOKORIĆ, Duhovnost - resurs za prevladavanje kriznih životnih situacija kod pripadnika karizmatskih zajednica, Ljetopis socijalnog rada, 21 (2014) 3, 425-452.

${ }^{19}$ Usp. Frederic O. FINKELSTEIN, William WEST, Jaya GABIN, Susan H. FINKELSTEIN, D. WUERTH, Spirituality, quality of life and dialiysis patient, Nephrol Dial Transplant, 22 (2007) 9, 2432-2434.

${ }^{20}$ Usp. Dučkić, Blažeka Kokorić, Duhovnost - resurs za prevladavanje kriznih...
} 
koji otkriva važnost prakticiranja osobne duhovnosti prilikom suočavanja sa stresorima poput bolesti, gubitaka i slično.

Prema vjerskom suočavanju, u životu postoje neizbježni stresori, no religijska samoidentifikacija i osobna duhovnost mogu biti dobar način suočavanja $s$ njima. Vjersko suočavanje bazira se na traženju vlastitih snaga, utjehe, otkrivanja smisla, prihvaćanju stanovitih životnih okolnosti te njihovo nadilaženje, ali u konačnici i u razvijanju vlastite otpornosti za nadolazeće teškoće. ${ }^{21}$ Cilj vjerskog suočavanja je mijenjanje svijesti potaknuto transcendentalnim iskustvom, što bi konkretno značilo osnaživanje za prelaženje vlastitih granica i limita u smislu: moći oprostiti, preuzeti odgovornost za svoju roditeljsku ulogu, potaknuti altruizam, promijeniti vlastito ponašanje i slično.

Rezultati vjerskog suočavanja vrlo su opipljivi jer direktno utječu na zdravlje osobe, pospješuju tjelesno i psihičko zdravlje te pozitivno utječu na ukupnu kvalitetu života. U skladu s tim postoje brojna istraživanja koja su potvrdila da prakticiranje duhovnosti može ublažiti negativne efekte traumatskih doživljaja, ${ }^{22}$ da proživljena osobna duhovnost ima pozitivan utjecaj na fiziološko funkcioniranja organizma i služi za očuvanje živčanog te imunološkog sustava, ${ }^{23}$ da transcendentalno iskustvo smanjuje štetan utjecaj stresnih okolnosti te može pozitivno utjecati na raspoloženje pojedinca, njegovo cjelokupno zdravstveno stanje, blagostanje te njegovu dobrobit te da osobna duhovnost pomaže pojedincu u očuvanju njegova mentalnog zdravlja. Stoga, religijska pripadnost, prakticiranje duhovnosti i vjerovanje u temeljne duhovne postavke - očituju se u nizu pozitivnih indikatora kao što su: razvijanje otpornosti, ostvarivanje međusobne podrške, pronalaženje dubljeg smisla, dolaženje do novih spoznaja o sebi i novih interpretacija životnih situacija sagledanih iz drugog kuta, ${ }^{24}$ implementiranje pozitivnih vrijednosti $u$ vlastiti život te kroz duhovni rast.

Duhovnost i religioznost su velik resurs jer daju jasnu strategiju kao odgovor na krizno stanje u kojem se pojedinac nalazi te duhovnost kao takva posjeduje terapijske elemente. Duhovnost oblikuje stil života te pomaže u suočavanju sa stresnim i kriznim situacijama. Vjersko suočavanje je način suočavanja koji nastaje kao odgovor na iskustvo bolesti, smrti ili gubitka voljene osobe i slično. ${ }^{25}$ Bazira se na traženju snage i utjehe kroz duhovnost te na njegovanju osobnog

${ }^{21}$ Adam Joel MRDJENOVICH, University counseling center practices regarding guidance on the health effects of religious/spiritual involvement (2009), Dissertation, Toledo, The University of Toledo, https://etd.ohiolink.edu/rws_etd/document/get/toledo1256083041/inline (04.10.2016).

${ }^{22}$ Usp. Teresa. E. SEEMAN, Fagan Linda DUBIN, Melvin SEEMAN, A critical review of the evidence for biological pathways, American Psychologist, 58 (2003) 1, 53-63.

${ }^{23}$ Usp. Jeff LEVIN, God, love, and health. Findings from a clinical study, Review of Religious Research, 42 (2001) 3, 277-293.

${ }^{24}$ Usp. Ante KOMADINA, Povijesni razvoj crkvene skrbi za bolesne, Služba Božja, 53 (2013) 3-4, 265-283.

${ }^{25}$ Usp. Mrdjenovich, nav. dj., 23-34. 
rasta kroz prihvaćanje i nadilaženje neizbježnih životnih teškoća i stresora. ${ }^{26}$ Duhovnost je važan aspekt osnaživanja pojedinca u obitelji za nošenje s teškim i stresnim životnim situacijama, no ona je ujedno i snažan izvor otpornosti. ${ }^{27}$ Obiteljska tragedija, neuspjeh, nevolja i razočaranje mogu pokrenuti promjene u obitelji te usmjeriti članove obitelji da iziđu jači i obogaćeni novim iskustvom. ${ }^{28}$

Nakon analiziranja duhovnosti u kontekstu istraživanja nekih od obiteljskih rizika željeli smo u ovom radu vidjeti u kojim sve obiteljskim rizicima duhovnost može biti izvor snage i otpornosti. Stoga smo u radu uzeli kvalitativni pristup jer je njime moguće dublje i sveobuhvatnije zahvatiti promatranu temu.

\section{Cilj istraživanja}

Dobiti uvid kako sudionici doživljavaju duhovnost u suočavanju s rizičnim okolnostima u obitelji.

\subsection{Istraživačko pitanje}

Kakvo je iskustvo sudionika koji intenzivno žive duhovni život o ulozi duhovnosti u suočavanju s rizicima u obitelji?

\subsection{Sudionici istraživanja}

U istraživanju je obuhvaćeno 12 sudionika koji subjektivno procjenjuju, a i njihova okolina, da žive duhovni život u svojoj svakodnevnici. Odabrani su stoga po kriteriju namjernog uzorkovanja jer se smatralo da nam te osobe mogu biti najbolji informatori o istraživanoj pojavi. Bile su to osobe koje njeguju duhovnost u svakodnevnom životu. Željela se osigurati i intrinzična motivacija sudionika o ulozi svojih životnih iskustava duhovnosti u nošenju s kriznim životnim okolnostima njihovih obitelji. Ovakvim odabirom sudionika istraživanja namjeravalo se omogućiti stjecanje novih spoznaja i produbiti razumijevanje načina kako doživljavaju ulogu duhovnosti u rizičnim okolnostima svojih obitelji te koju ulogu ima duhovnost u prevladavanju životnih kriza. Dubinski intervjui su provedeni s 8 žena i 4 muškarca u dobi od 33 do 57 godina života. Vlastitu obitelj s djecom ima 9 sudionika, troje sudionika pripada redovničkoj

\footnotetext{
${ }^{26}$ Usp. Kenneth I. PARGAMENT, Harold G. KOENIG, Lisa M. PEREZ, The many methods of religious coping. Development and initial validation of the RCOPE, Journal of Clinical Psychology, 56 (2000) 4, 519-543.

${ }^{27}$ Usp. Froma WALSH, Strengthening Family Resilience, New York - London, The Guilford Press, 2016, 368.

${ }^{28}$ Zdravka LEUTAR, Duhovnost kao resurs osnaživanja u palijativnoj skrbi, Zbornik sažetaka, Slavonski Brod (09.09.2015), https://bib.irb.hr/prikazi-rad?\&rad=775405 (04.10.2016).
} 
zajednici, ali imaju iskustvo s krizama vezanim uz svoju primarnu obitelj. Svi sudionici imaju visoku stručnu spremu. Iako se nije tražila pripadnost nekoj zajednici kao uvjet, ispostavilo se da svi sudionici pripadaju nekoj od duhovnih zajednica unutar Katoličke crkve.

\subsection{Metoda i način provedbe istraživanja}

Istraživanje je provedeno za potrebe ovog rada. U istraživanju se koristio kvalitativni pristup budući da je riječ o temi koja zahtijeva visok stupanj osobnog samootkrivanja sudionika istraživanja, dublje i detaljnije iznošenje vlastitih iskustava o duhovnosti te o prevladavanju kriznih životnih situacija u osobnom i obiteljskom životu. Podaci su se prikupljali tehnikom polustrukturiranog dubinskog intervjua čiji je cilj omogućiti bolje razumijevanje značenja koje ispitivano iskustvo ima za sudionike. ${ }^{29}$ Istraživanje je provedeno u skladu s temeljnim etičkim načelima istraživanja. Sudionike se pozvalo putem elektroničke pošte na sudjelovanje. Objašnjeni su im ciljevi i svrha istraživanja, princip dobrovoljnosti, povjerljivosti i anonimnosti, te mogućnost odustajanja od sudjelovanja $\mathrm{u}$ istraživanju u bilo kojem trenutku. Sukladno iskazanom interesu i mogućnostima, zainteresirani sudionici istraživanja naknadno su telefonski kontaktirani te je individualno sa svakim dogovoren termin i mjesto provođenja intervjua. Svaki razgovor sniman je diktafonom (uz prethodnu suglasnost sudionika), nakon čega je transkribiran. Intervjui su u prosjeku trajali 50 minuta.

\subsection{Obrada podataka}

Za obradu podataka korišten je postupak tematske analize. Tematska analiza je proces identificiranja, analiziranja i izvještavanja prema tzv. obrascima (temama) koje se prepoznaju unutar podataka. Tematska analiza odnosi se na organizaciju i opisivanje podataka u bogatim detaljima, no vrlo često ide iznad toga te se odnosi na različite aspekte interpretacije. ${ }^{30}$ Tema je obrazac unutar podataka koji se načelno može odrediti na dva načina: induktivnim ili deduktivnim načinom. Za analizu smo odabrali deduktivan način, koji se naziva i teorijskim, pri čemu se teme određuju u skladu s teorijskim ili analitičkim interesom istraživača. Ovaj pristup često dovodi do manje detaljnih opisa podataka u cjelini, a više je usmjeren na detaljniju analizu nekih aspekata podataka.

\footnotetext{
${ }^{29}$ Goran MILAS, Istraživačke metode u psihologiji i drugim društvenim znanostima, Jastrebarsko, Naklada Slap, 2005, 580.

${ }^{30}$ Virginia BRAUN, Victoria CLARKE, Using thematic analysis in psychology, Qualitative Research in Psychology, 3 (2006) 2, 77-101.
} 


\section{Rezultati i rasprava}

Analizom rezultata došlo se do sedam tema: 1 . obiteljski rizici i integracija duhovnosti, 2 . izvori snage u duhovnosti za obitelj u riziku, 3. dobrobit duhovnosti, 4. autentičnost u življenju duhovnosti, 5. krize na duhovnom putu hoda obitelji u riziku, 6. predispozicije za učinkovito djelovanje duhovnosti, 7. duhovnost kao resurs snage i otpornosti koji je uvijek moguć. Svaka od sedam osnovnih tema uključuje podteme koje su pronađene $u$ analizi transkribiranih intervjua. Neke od podtema će biti potkrijepljene i direktnim izjavama sudionika te će biti interpretirane u kontekstu postojećih istraživanja koje smo prikazali u uvodnom dijelu ovoga rada, a i u istraživanjima koja se bave duhovnošću kao resursom obiteljske otpornosti.

\subsection{Obiteljski rizici i integracija duhovnosti}

Tablica 1. Nadređene i podređene teme obiteljskih rizika i integracije duhovnosti

\begin{tabular}{|l|l|}
\hline Nadređene teme: & Podređene teme \\
\hline Rizik bolesti u obitelji & $\begin{array}{l}\text { Kancerogene bolesti } \\
\text { Alzheimerova bolest } \\
\text { Duševna oboljenja } \\
\text { Anoreksija } \\
\text { Iskustvo neizvjesnosti ishoda bolesti }\end{array}$ \\
\hline Starost i starenje & $\begin{array}{l}\text { Tijek onemoćalosti roditelja } \\
\text { Zamjena uloga roditelj }- \text { dijete } \\
\text { Briga za starije i nemoćne roditelje }\end{array}$ \\
\hline Invaliditet u obitelji & $\begin{array}{l}\text { Invaliditet odrasle osobe u obitelji } \\
\text { Dijete s teškoćama u razvoju }\end{array}$ \\
\hline Kvalitativno insuficijentna obitelj & $\begin{array}{l}\text { Patološke pojave u obitelji } \\
\text { Stranputice i traženja djece u obitelji } \\
\text { Ovisnosti članova obitelji } \\
\text { Krize u braku }\end{array}$ \\
\hline Siromaštvo u obitelji & $\begin{array}{l}\text { Nezaposlenost } \\
\text { Niske mirovine } \\
\text { Nemogućnost dobivanja invalidske mirovine }\end{array}$ \\
\hline Smrt u obitelji & $\begin{array}{l}\text { Terminalna faza člana obitelji } \\
\text { Smrt } \\
\text { Žalovanje } \\
\text { Suosjećanje s velikom boli članova obitelji }\end{array}$ \\
\hline Promjene koje rezultiraju ranjivošću \\
odnosa & $\begin{array}{l}\text { Bol u bliskim vezama } \\
\text { Nasilje u bliskim vezama } \\
\text { Prekid intimnog prijateljstva } \\
\text { Razilaženje u bliskim vezama }\end{array}$ \\
\hline
\end{tabular}


Nakon analize intervjua došlo se do velikog broja obiteljskih rizika u kojima su sudionici koristili duhovnost kao resurs vlastite i obiteljske otpornosti kako pokazuje i tablica 1. Sudionici to izjavljuju:

»Muž nakon rata ne nalazi posla. Cijelo ovo vrijeme u svemu se oslanjamo na vlastite snage da bi 1998. doživjeli krah - razvod, sin eksperimentira s drogama, kći na rubu anoreksije, muž nezaposlen pije, ja završim na operaciji jajnika i u depresiji« (S. 5). ${ }^{31}$

Ovdje je zapravo moguće uočiti više obiteljskih rizika u kojima su se našli članovi obitelji i ta ih situacija upravo dovodi do traženja Stvoritelja. Suočavanje sa stresom je proces u kojem pojedinac koristi raspoložive resurse i usvojene strategije suočavanja, među kojima se kod osoba s izraženom religijskom samoidentifikacijom mogu identificirati i resursi vezani uz osobna duhovna iskustva, vjerska uvjerenja, percipiranu kontrolu osjećaja smisla i svrhe života te doživljaj podrške od strane vjerskih zajednica. ${ }^{32} \mathrm{U}$ tom kontekstu ista sudionica izražava:

»Gospodin tada izlijeva milosti na nas. Muž je osnovao vlastitu firmu koja i danas uspješno radi, ja sam se počela liječiti od depresije i na grupnoj terapiji čula za neokatekumensku zajednicu, sin je krenuo u Tabor i na terapije da se riješi posljedica drogiranja te je položio prijemni i upisao željeni fakultet kojeg je i završio. Kći, koja je s prilično problema završila osnovnu školu u srednjoj postaje odličan učenik« (S. 5).

Složenost teških obiteljskih okolnosti u kojima se duhovnost prepoznaje kao resurs podrške i otpornosti članova obitelji moguće je promotriti i kroz druge iskaze:

»Dijagnoza nije bila dobra. Metastatski adenokarcinom. Zahvaćen je bio cijeli organizam, bolest je galopirajuće napredovala. U tim trenucima nema mjesta subjektivnosti, kako neki pomišljaju. Sve oko tebe vrišti objektivnim podatcima, konkretnim dokazima da se život gasi, da će nastupiti vrijeme suočavanja s boli i da će se dogoditi rastanak... i da ćeš sve to morati nekako proživjeti i preživjeti, ako zbog ničega, onda zbog nje, mame koja je bolesna. Njezin je životni put bio put traganja. Nije rođena u tradicionalnoj katoličkoj obitelji, nije poznavala Boga, tata također, ali splet gotovo nevjerojatnih životnih okolnosti i čudesnih Božjih zahvata dovelo ju je do dubokog iskustva vjere koju je praktično i izuzetno jednostavno živjela« (S. 4).

Slična situacija integracije duhovnosti se navodi i kod rizika Alzheimerove bolesti majke.

»Radi se o iskustvu duge bolesti (Alzheimer) moje mame, više od 7 godina (što smo mi primijetili) od kojih zadnje 3 i pol godine na krevetu, ovisna potpuno o

\footnotetext{
${ }^{31}$ Brojevi navedeni u zagradama nakon navoda citata označavaju redni broj sudionika istraživanja. Prilikom transkribiranja svaki intervju je označen brojem.

${ }^{32}$ Usp. Christopher G. ELLISON, Daisy FAN, Daily spiritual experiences and psyhological wellbeing among US adults, Social Indicators Research, 88 (2008) 2, 247-271.
} 
pomoći drugog. Ovih godina prošli smo, kao obitelj, mnoga i raznovrsna iskustva boli, mnoga pitanja, neizvjesnosti... Jedno mogu sa sigurnošću reći: da je moja mama bila žena velike i konkretne vjere i da je život i križ prihvaćala sa svim njegovim zahtjevima, iznenađenjima i intenzivnošću« (S. 12).

Navedena duhovna iskustva ojačavaju, proširuju te određuju način na koji pojedinac gleda na sebe, na smisao bolesti, svoga života i na svoju ulogu u svijetu. ${ }^{33}$ Neka istraživanja religioznosti pokazala su da je vjera u životnim poteškoćama intenzivnija i da se pojedinci više okreću duhovnoj dimenziji čovjeka. ${ }^{34}$ Lang je ispitivao ulogu vjere u prevladavanju životnih problema i došao do spoznaje da je ona značajan faktor u nadilaženju životnih problema. ${ }^{35}$ Upravo ispitivanje značenja vjere u nošenju s invaliditetom došlo je do izražaja u tri funkcionalna područja: vjera kao okvirna orijentacija kod prvog susreta s dijagnozom, vjera kao olakšanje u odgovoru na pitanja »zašto«, vjera kao sredstvo pronalaženja smisla.

Duhovnost kao resurs obiteljske otpornosti članova je prisutna u svim obiteljskim rizicima. ${ }^{36}$ Ovdje su dakle navedeni neki od rizika. Istraživanja ${ }^{37}$ su pokazala da religiozne obitelji, u odnosu na one koje to nisu, za vrijeme trajanja nesigurnosti, neizvjesnosti i stresa imaju veću razinu vjere i nade u dobar ishod, rjeđe imaju problema s alkoholizmom i drogom, depresijom, pokušajima suicida i rjeđe se razvode. ${ }^{38}$ Stoga ćemo u nastavku promatrati koji su to zapravo izvori snage u duhovnosti za obitelj u riziku.

${ }^{33}$ Usp. Juliet ROTHMAN, Spirituality. What we can teach and how we can teach It, Journal of Religion and Spirituality in Social Work, 28 (2008) 1, 161-184.

${ }^{34}$ Usp. Zdravka LEUTAR, Religioznost obitelji u Hrvatskoj, Austriji i Poljskoj, Bogoslovska smotra, 71 (2001) 1, 85-107.

${ }^{35}$ Usp. Slobodan LANG, From Gulf War Syndrome to Balkan War Syndrome, Croatian medical journal, 42 (2001) 2, 205-209.

${ }^{36}$ Usp. Gordana BERC, Obiteljska otpornost - teorijsko utemeljenje i primjena koncepta u socijalnom radu, Ljetopis socijalnog rada, 19 (2012) 1, 145-167.

${ }^{37}$ Usp. Walsh, nav. dj., 368-390.

${ }^{38}$ Usp. George A. BONANNO, Loss, trauma, and human resilience. Have we underestimated the human capacity to thrive after extremely aversive events?, American Psychologist, 59 (2004) 1, 20-28. 


\subsection{Izvori snage u duhovnosti za obitelj u riziku}

Tablica 2. Nadređene i podređene teme izvora snage u duhovnosti za obitelji u riziku

\begin{tabular}{|c|c|}
\hline Nadređene teme: & Podređene teme \\
\hline $\begin{array}{l}\text { Spoznaja vrednote } \\
\text { ljubavi }\end{array}$ & $\begin{array}{l}\text { Bog je ljubav } \\
\text { Božje sam ljubljeno dijete } \\
\text { Ljubav temelj vlastitog života }\end{array}$ \\
\hline $\begin{array}{l}\text { Spoznaja vrednota vjere } \\
\text { i nade }\end{array}$ & $\begin{array}{l}\text { Bezuvjetno predanje Bogu } \\
\text { Marija, duhovna majka i zagovornica u kriznim situacijama } \\
\text { Križ, sredstvo rasta i sazrijevanja } \\
\text { Doživljaj Boga koji čeka i prašta } \\
\text { Smisao trpljenja članovi pronalaze u Isusu Kristu }\end{array}$ \\
\hline $\begin{array}{l}\text { Osnaživanje } \\
\text { članova obitelji kroz } \\
\text { prakticiranje vjere }\end{array}$ & $\begin{array}{l}\text { Molitva } \\
\text { Božja Riječ } \\
\text { Meditacija } \\
\text { Sakramenti } \\
\text { Euharistija } \\
\text { Ispovijed } \\
\text { Dnevni ispit savjesti } \\
\text { Duhovno vodstvo }\end{array}$ \\
\hline $\begin{array}{l}\text { Zajedništvo kao sredstvo } \\
\text { podrške članovima }\end{array}$ & $\begin{array}{l}\text { Zajednička molitva } \\
\text { Uključivanje i aktivno sudjelovanje u duhovnim zajednicama } \\
\text { Hodočašća } \\
\text { Blizina sudionika na susretu } \\
\text { Dijeljenje duhovnih iskustava } \\
\text { Međusobna praktična pomoć članova duhovnih zajednica }\end{array}$ \\
\hline $\begin{array}{l}\text { Permanentna duhovna } \\
\text { edukacija }\end{array}$ & $\begin{array}{l}\text { Seminari } \\
\text { Predavanja } \\
\text { Diskusije o Bogu } \\
\text { Praćenje duhovnog programa kroz medije }\end{array}$ \\
\hline $\begin{array}{l}\text { Obnavljanje i rast u } \\
\text { duhovnosti }\end{array}$ & $\begin{array}{l}\text { Pronalaženje vremena tišine i osame } \\
\text { Duhovne vježbe } \\
\text { Traženje Stvoritelja u svojoj okolini: ljudima i prirodi }\end{array}$ \\
\hline $\begin{array}{l}\text { Prakticiranje duhovnosti } \\
\text { u obitelji }\end{array}$ & $\begin{array}{l}\text { Prakticiranje vjerskih praksi } \\
\text { Bliskost članova u obitelji } \\
\text { Duhovne vrijednosti roditelja kao poticaj i osnažujući faktor djeci } \\
\text { Vrednote vjere i nade roditelja poticaj i inspiracija za djecu } \\
\text { U duhu vjere razumijevanje za slabosti članova obitelji }\end{array}$ \\
\hline
\end{tabular}

Analizirajući intervju sudionika utvrđeno je puno izvora snage koje pruža duhovnost obitelji u riziku. Neki od njih se odnose na spoznaju Boga ljubavi:

»Promišljanje o značenju duhovnosti u susretu s obiteljskim rizicima je izazov da samoj sebi osvijestim tu stvarnost koju je nekako teško uobličiti riječima. (...) U mojem životu je najvažnija spoznaja da je Bog ljubav i da sam doista Božje ljubljeno dijete. Ona je temelj moga života. To nije neka statična spoznaja, već je to životni put, pun dinamike i izazova. Pokušat ću izreći kako se na tom putu susrećem s patnjom mojih najbližih. Mogu to usporediti sa stanjem djeteta kojeg boli zub: kad je u majčinu krilu, iako ga boli zub dijete doživljava sigurnost 
i utjehu zbog blizine majke koja ga voli. Dijete će puno teže podnositi istu bol samo na ulici, bol će biti beznadna zbog samoće, napuštenosti, nesigurnosti... Božja ljubav u susretu s patnjom donosi mi utjehu, oslonac, sigurnost i snagu za nadvladavanje patnje. Tada me patnja ne ubija nego preobražava i jača moj život« (S. 1).

Iskaz sudionika upućuje na duboku spoznaju Božje ljubavi koja daje sigurnost i najveći izvor snage za život. Na temelju iskaza smo definirali podteme: Spoznaja da je Bog ljubav, Spoznaja da sam Božje ljubljeno dijete, Ljubav - temelj vlastitog života. Kad tumači trojstvenog Boga sam ga sv. Augustin navodi kao Boga ljubavi. Ako ljubav kojom Otac ljubi Sina i Sin ljubi Oca neiskazivo očituje zajedništvo obojice, što je dosljednije nego da se navlastito nazove Ljubavlju Duh koji je obojici zajednički? Razumnije se, vjeruje ili shvaća to da u Trojstvu nije samo Duh Sveti ljubav. Unatoč tome, on se zbog onoga što je kazano ipak ne naziva zaludu navlastito Ljubav. ${ }^{39}$

»Životni put nije uvijek obasjan suncem, tj. sigurnošću; oluje patnje, brige i osobne slabosti zastiru i zamagljuju spoznaju Božje ljubavi, donose sumnje, tjeskobu, pitanja, unutarnju borbu... Tada se kroz molitvu i sakramente, posebno euharistiju, susret s Božjom riječju, susrete s ljudima vidik čisti i bistri, unutarnji 'ja' zašuti i ponizno prepušta prostor Duhu Svetom koji tješi i brani, koji izlijeva novu snagu u moje srce« (S. 10).

Više autora ${ }^{40}$ navodi djelotvornost molitve kao izvor snage u stresnim situacijama stoga je ističemo kao podtemu. Molitva ima utjecaj na smanjenje stresa, tjeskobe, beznađa i očaja, te ima ulogu osnaživanja. ${ }^{41}$

»Došla je godina 2014., moja treća trudnoća. Desetak dana prije poroda, nakon tegoba zbog kojih sam se ranije javila u bolnicu, rekli su mi da imam karcinom jajnika... Napravljen je carski rez i operacija jajnika zahvaćenog karcinomom. Metastaze po trbušnoj šupljini. Kemoterapija 20 dana nakon poroda. Nisam smjela dojiti da držim tijelo u snazi zbog onoga što me čeka. U glavi i srcu - tupost, kao obrana od šoka. Tada započinje pravi duhovni rat! Rat za moju dušu! Podiglo se silno mnoštvo ljudi, i znanih i neznanih, prijatelja i njihovih prijatelja. Svi su htjeli pomoći. I svima beskrajno hvala na tome. Zauvijek su u mojim molitvama. Ali najvažnije je bilo to što su se podigle i organizirale mnoge molitvene grupe u molitvi za moje zdravlje. Svakodnevno sam dobivala informacije o tome gdje se u Hrvatskoj, čak i u drugim zemljama, moli za mene. Poslije ću

\footnotetext{
${ }^{39}$ Usp. Aurelije AUGUSTIN, Trojstvo, Split, Služba Božja, 2009, 606.

${ }^{40}$ Usp. Jeff LEVIN, Prevalence and Religious Predictors of Healing Prayer Use in the USA. Findings from the Baylor Religion Survey, Journal of Religion and Health, 55 (2016) 4, 1136-1158; usp. Zdravka LEUTAR, Marta RADOŠ, Ivan LEUTAR, Podrška mladima s intelektualnim teškoćama u zajednici Vjera i svjetlo, u: Medina Vantić Tanjić, Milena Nikolić (ur.), Unapređenje kvalitete života djece i mladih, Tematski zbornik VII. međunarodne naučno-stručne konferencije »Unapređenje kvalitete života djece i mladih«, Tuzla, Udruženje za podršku i kreativni razvoj djece i mladih i Edukacijsko rehabilitacijski fakultet Tuzla 2016, 427-440.

${ }^{41}$ Usp. Andrew L. WHITEHEAD, Samuel L. PERRY, Religion and support for adoption by samesex couples. The relative effects of religious tradition, practices, and beliefs, Journal of Family Issues, 37 (2016) 6, 789-813.
} 
tek postati svjesna snage molitve. Snage koja me nosila i koja jednostavno nije dopustila da potonem, klonem duhom, niti da se išta iskomplicira i krene po zlu« (S. 5).

Molitva čini važan aspekt očuvanja emocionalnog i mentalnog zdravlja jer ima izravne fiziološke učinke kroz pozitivne emocije i pozitivna očekivanja. ${ }^{42}$ Upravo je važan aspekt i u molitvi spoznaja ljubavi koju pojedinac osjeća i koja postaje izvor osnaživanja i liječenja same osobe. Ovdje je riječ o molitvi, ali su navedene i došle do izražaja određene konkretne prakse unutar Katoličke crkve koja imaju blagotvoran učinak na člana obitelji: sakramenti, osobito ispovijed, ${ }^{43}$ euharistija, ${ }^{44}$ Božja Riječ, post, ${ }^{45}$ dijeljenje iskustava s duhovnim osobama, slušanje katoličkog radija, razmišljanje o Bogu, razgovori o Bogu i duhovnim stvarima ${ }^{46}$ bezuvjetno i bezgranično predanje Bogu. Stoga sudionici navode:

»Teško mi je to protumačiti, teško je bilo i u tim trenucima tumačiti ljudima oko sebe odakle nam snaga. A, uočavali su je. Osobito kod mame. Često bi komentirali kako u svoj muci ona blista. Tajna je u njezinu osmišljavanju i prihvaćanju sebe i bolesti, ali i duboka vjera u Boga koji uvijek čini dobro. I činio je dobro, svakog jutra kad ti daruje da, uza svu bol koja te slama, ustaneš, da jedeš, spremaš ispite na faksu, kuhaš mami omiljena jela i ona ih s osmijehom dočekuje, iako znamo da ne može baš jesti, satima boraviš u bolnici, slušaš prognoze liječnika koje nisu nimalo dobre, gledaš kako mama gubi na težini, kako prima 12 sati prvu kemoterapiju, s osmijehom se međusobno hrabrimo, molimo, čitamo Bibliju, s radošću slušam priče njezine mladosti... i na kraju dana za sve to dobiješ snagu te u skrovitosti sobe izgovaraš: 'Slava Ocu i Sinu i Duhu Svetomu...' Slava za sve... svijet će reći paradoks, neshvatljivo... nikad mu nisam, bez obzira na sve, mogla prestati davati slavu. Snaga je u tim trenucima dolazila iz pet izvora: euharistija, molitva, Biblija, post i moja obitelj« (S. 9).

Uza sve ove izvore snage, dolazi do izražaja i međusobna podrška i blizina članova (kohezivnost obitelji) u kriznim situacijama za obitelj, ona postaje izvor snage.

»A, obitelj! Bila sam ponosna na ljubav koju smo si međusobno bili kadri darovati. Mama je ponavljala da ona ne bi mogla živjeti bez ljubavi tate, brata i mene. Bili smo stalno zajedno, govorili si koliko smo si važni, koliko nam je lijepo u svoj toj muci jer smo skupa, jer smo blizu... Spoznala sam tada da je vjera velik dar i da Bog uistinu sve ljude želi darovati, stvar je u nama, želimo li prihvatiti taj dar. Moja obitelj to je prihvatila« (S. 8).

\footnotetext{
${ }^{42}$ Usp. Jeff LEVIN, Prayer, love, and transcendence: An epidemiologic perspective, u: Warner, K. Schaie, Neal Krause, Alan Booth (ur.), Religious influences on health and well-being in the elderly, New York, Springer, 2004, 69-95.

${ }^{43}$ Usp. Ivan LEUTAR, Wiederentdeckung des »Heligen« am Beispiel des Wallfahrtsortes Medjugorje, Saarbrücken, Fromm Verlag, 2011, 290-299.

${ }^{44}$ Isto, 247

${ }^{45}$ Isto, 313.

${ }^{46}$ Usp. Ivan LEUTAR, Leopold NEUHOLD, Zdravka LEUTAR, Obilježja hodočasnika - motivi i značenje Hodočašća, Bogoslovska smotra, 1 (2007), 217-243.
} 
Stoga možemo tvrditi, kao što pronalazimo i u literaturi, da se duhovnost očituje kao pozitivna snaga u obiteljskim odnosima, koja pomaže članovima obitelji da usred poteškoća prevladaju osjećaj nemoći i očaja te da oslanjanjem na vjeru ojačaju svoje zajedništvo i osjećaj samopouzdanja ${ }^{47}$ Osjećaj zajedništva i blizine članova u obitelji i zajednici u kojoj članovi prakticiraju svoju vjeru utvrđen je u brojnoj literaturi i o tome možemo pronaći iskaze kod više autora. ${ }^{48}$ Drugi važni izvori snage koje članovi obitelji navode su: doživljaj Marije kao duhovne Majke i zaštitnice ${ }^{49}$ te zagovornice, križ i teškoće kao blagoslov - najdragocjenije doba rasta i sazrijevanja osobnosti, karizmatski seminari, ${ }^{50}$ predavanja, molitvene zajednice, aktivno uključivanje u različite duhovne zajednice, ${ }^{51}$ hodočašće, ${ }^{52}$ duhovno vodstvo, doživljaj Boga koji čeka i prašta. Moguće je to prepoznati i u iskazima sudionika.

»Moja želja za Bogom i duhovnim iscjeljenjem je bila tolika da sam jedva čekala kad ću poći na seminare, predavanja, nagovore, u molitvenu zajednicu član koje sam postala, a koja nosi znakovito ime: 'Nanovo rođeni'. Članovi 'Nanovo rođenih' postali su više od prijatelja, postali su mi kao obitelj. I dalje sam 'letjela' na krilima molitve svih ljudi koji su me se spominjali. Učlanila sam se u školu molitve kod Kristofora, polazila svaki seminar, predavanje, hodočašće do kojeg sam mogla doći. Cijelo to vrijeme odrađivala sam kemoterapije, ali, koliko god to čudno zvučalo, bolest je bila zadnja stvar na koju sam mislila. Mislila sam na Boga, na sve ono 'smeće' koje je zatrovalo moju dušu, a koje je sad trebalo pročistiti. Ustvari, nisam niti trebala misliti o tome. Prepustila sam se molitvi i Gospodinu, a čišćenje je samo došlo« (S. 5).

Uz ovakve izjave moguće je uočiti još drugih podtema koje se odnose na izvore snage i podrške obitelji u kriznim situacijama: roditeljsko pronalaženje snage u vjeri i nadi, duhovne vrijednosti roditelja, duhovne vježbe, traženje Stvoritelja u prirodi, traženje Stvoritelja u stvorenjima, pronalaženje vremena tišine i osame, blizina sudionika na susretima, u Bogu osmišljavanje ljudske opakosti i zloće, ispit savjesti, smisao trpljenja u Isusu Kristu. ${ }^{53} »$ Tako osnažena mogu se s unutarnjim mirom i vedrinom suočiti s konkretnom situacijom, pomoći si koliko mogu, a ostalo prepusti Bogu« (S. 11).

\footnotetext{
${ }^{47}$ Usp. Forma WALSH, Spiritual diversity. Multifaith perspectives in family therapy, Family Process, 49 (2010) 3, 330-348.

${ }^{48}$ Usp. Leutar, Neuhold, Leutar, nav. dj; Zdravka LEUTAR, Ivan LEUTAR, Religioznost studenata i njezin utjecaj na svakodnevni život, Obnovljeni život, 62 (2007) 2, 151-176; Marijan JURČEVIĆ, Zajedništvo u Crkvi - vrijednost u krizi?, Bogoslovska smotra, 71 (2001) 2-3, 401-413.

${ }^{49}$ Ivan Leutar, Wiederentdeckung des »Heligen «..., 255.

${ }^{50}$ Usp. Anita DUČKIĆ, Slavica BLAŽEKA KOKORIĆ, Iskustvo osobne i obiteljske duhovnosti kod pripadnika karizmatskih zajednica »Dobri Pastir« i »Maranatha«, Nova prisutnost, 12 (2014) 2, 239-259.

${ }^{51}$ Usp. isto.

${ }^{52}$ Usp. Leutar, Neuhold, Leutar, nav. dj.

${ }^{53}$ Ivan Leutar, Wiederentdeckung des »Heligen«..., 267-290.
} 


\subsection{Dobrobit duhovnosti za obitelj u riziku}

Tablica 3: Nadređene i podređene teme dobrobiti duhovnosti za obitelj u riziku

\begin{tabular}{|c|c|}
\hline Nadređene teme: & Podređene teme \\
\hline Preobrazba obitelji & $\begin{array}{l}\text { Aktivno pristupanje procesu rješavanja obiteljskih problema } \\
\text { Bezizlazne situacije se prepuštaju Bogu, pouzdanje u njegovu } \\
\text { pomoć i providnost } \\
\text { Međusobno praštanje unutar obitelji } \\
\text { Suosjećanje } \\
\text { Radost i blag izraz lica } \\
\text { Intenzivno prakticiranje vjere } \\
\text { Rast i pozitivne promjene članova obitelji } \\
\text { Poticaj - voljeti svakog čovjeka iskreno i istinski }\end{array}$ \\
\hline $\begin{array}{l}\text { Spoznaja neizmjerne } \\
\text { Božje ljubavi }\end{array}$ & $\begin{array}{l}\text { Utjeha, oslonac, sigurnost i snaga u nadvladavanju krize } \\
\text { Patnja ne ubija život nego ga preobražava i jača } \\
\text { Unutarnji mir obitelji } \\
\text { Unutarnja sloboda } \\
\text { Sve u životu ima svoj dublji smisao } \\
\text { Prihvaćanje životnih izazova }\end{array}$ \\
\hline $\begin{array}{l}\text { Otpornost članova } \\
\text { obitelji }\end{array}$ & $\begin{array}{l}\text { Jačanje vjere } \\
\text { Prepoznavanje darovanosti osobama na životnom putu } \\
\text { Mogućnost »rezanja vrpce« u odnosima koji nemaju budućnost } \\
\text { Stabilnost i sigurnost djece } \\
\text { Okolina zamjećuje otpornost obitelji u teškoj situaciji }\end{array}$ \\
\hline
\end{tabular}

Produbljivanje i rast $\mathrm{u}$ duhovnosti sredstvima koje navode sudionici dovodi do stanovite dobiti za pojedince i cijelu obitelj. U tablici 3 je to prikazano kroz tri nadređene teme dobrobiti duhovnosti za obitelj u riziku: transformacija obitelji, spoznaja Božje ljubavi i otpornost članova obitelji.

»Nama kao roditeljima vjera je dala snagu za vlastiti život i brak, nadu da ćemo ipak na vrijeme stići posvjedočiti vjeru i svojoj djeci te popraviti štetu učinjenu u doba kada smo se oholili i oslanjali na svoju pamet. Naučili smo: ne gubiti ovu nadu, ne padati u očaj i vjerovati da će Bog, po zagovoru svoje majke Marije i svih svetih nadoknaditi našoj djeci sve propuste koje smo činili. Spremni smo svjedočiti i drugima sva ova čuda koje je Bog činio u našim životima i nastavlja ih činiti.«

Sudionici svjedoče o transformaciji svoje obitelji nakon aktivnog uključivanja i rješavanja problema obitelji, a ono što ih nadilazi s pouzdanjem predaju i prepuštaju Bogu jer su iskusili u obiteljskim krizama njegovu neizmjernu ljubav koja im je utjeha, oslonac, sigurnost i snaga u nadilaženju kriznih situacija.

»Ne mogu ni zamisliti kako bi tekao život nakon mamine smrti da nije bilo oslonca koji mi je Bog darovao u trenucima koji nisu bili laki, u trenucima žalovanja, tuge, navikavanja na život bez fizičkog prisustva osobe koja mi je značila najviše na svijetu. Iskustvo je to koje je duboko promijenilo mene kao osobu, sad, nakon gotovo deset godina, mogu posvjedočiti da je to iskustvo najdragocjenije 
u mojem životu, da me učinilo boljom osobom, otvorenijom za prihvaćanje, slobodnijom, ojačalo je moju vjeru, produbilo odnos s Bogom... Proživjela sam i preživjela pohod križa kojeg, vjerujte, nisam mislila da bih mogla preživjeti. Bog mi je bio veliki pomoćnik, baš onako kako ga se opisuje u Psalmima. Neka mu je slava na svemu što nam daruje!« (S. 4).

Sudionici prepoznaju tu dobit upravo u radosti, vedrini koju osjećaju te na osobit način po unutarnjem miru koji su dobili putem hoda u vjeri u životnim izazovima.

»Promišljanja... analiziranja... molitva... pad... uspon... opet pad... agonija... molitva... a najgore od svega - Božja šutnja! O, koliko sam molila za znak, za samo malu pomoć s njegove strane, ali ne, pustio me da sama odlučim... I donijela sam odluku, doslovno zadnje jutro, jutro ispred bolnice - idem! I osjetih kako se polaaaako vraća mir. Taj toliko potreban mir!... Ponovo sam postajala sretna. Gospodine, hvala ti, bez obzira što si do sada šutio, ali povratkom mira u dušu osjećam da blagoslivljaš moju odluku. (...) »Mjeseci i godina koja je slijedila nakon toga nije bila laka, ali kada hodaš uz Gospodina, ljubeći svoj križ jer si svjestan da te taj križ vodi k njemu, svaka teškoća postaje blagoslov!« (S. 5).

Drugi autori ${ }^{54}$ govore o duhovnosti kao egzistencijalnom odnosu s Bogom koji potiče osjećaj smisla, svrhe i poslanja u životu. Dovodi do olakšanja od egzistencijalne tjeskobe i pruža osjećaj sigurnosti.

\subsection{Autentičnost u življenju duhovnosti}

Tablica 4. Nadređene i podređene teme autentično življene duhovnosti obitelji u riziku

\begin{tabular}{|c|c|}
\hline Nadređene teme: & Podređene teme \\
\hline $\begin{array}{l}\text { Transparentnost unutar } \\
\text { obitelji }\end{array}$ & $\begin{array}{l}\text { Sve činiti iz ljubavi, ne iz dužnosti } \\
\text { Stupanje u sakramentalni brak } \\
\text { Primjer duhovnog života supruge privlači muža } \\
\text { Zajednička molitva roditelja za djecu, dovodi do transformacije } \\
\text { dječjeg ponašanja } \\
\text { Nadoknađivanje životnih propusta roditeljstva putem aktivnog } \\
\text { djelovanje u zajednici - čuvanjem i brigom za djecu mlađih članova }\end{array}$ \\
\hline $\begin{array}{l}\text { Transparentnost } \\
\text { življenja duhovnosti u } \\
\text { okolini }\end{array}$ & $\begin{array}{l}\text { Autentično življenje duhovnih osoba: »Po djelima ćete ih } \\
\text { prepoznati« } \\
\text { Svjedočenje vjere vlastitim djelima } \\
\text { Svakodnevna inspiracija: »Krist najveći uzor« } \\
\text { Zauzimanje za obespravljene u svojoj okolini } \\
\text { Ušutkati svoj »ja« i u poniznosti srca prepustiti Duhu Svetom koji } \\
\text { tješi i ulijeva novu snagu }\end{array}$ \\
\hline
\end{tabular}

\footnotetext{
${ }^{54}$ Usp. Ingeborg E. HAUG, Spirituality as a Dimension of Family Therapists' Clinical Training, Contemporary Family Therapy, 20 (1998) 4, 471-483.
} 
Na temelju analize intervjua utvrđena je i važnost transparentnog življenja duhovnosti i način kako se ona očituje. U tablici su vidljive dvije nadređene teme koje uključuju nekoliko podređenih tema. Transparentnost življene duhovnosti u krizama je moguća kroz transparentnost življenja u vlastitoj obitelji. Najviše je naglašen zapravo vlastiti primjer života. O duhovnosti nije potrebno puno govoriti nego se ona treba uočiti u djelovanju članova u obitelji i onda ona ima djelotvornu snagu unutar cijele obitelji.

»Osjetim da mami i braći puno znači moja prisutnost (kad mogu doći) i smijem reći da im na neki način Božja ljubav postaje bliža, da Božji mir i povjerenje u Boga prelazi i na njih« (S. 11).

Govoriti o Božjoj ljubavi, a ne pokazati je vlastitim djelima ne donosi ploda. Članovi obitelji je trebaju prepoznati po međusobnoj ljubavi i suosjećanju samih članova obitelji.

»Ne ulazimo s djecom u verbalne diskusije nego samo svjedočimo promijenjenim životom. Vide da smo Boga stavili na prvo mjesto. Prije svega, djeci je važno ne moralizirati - pozivamo ih na čistoću opominjući ih isključivo vlastitim iskustvom. Kćeri opisujem teške posljedice koje pobačaj ostavlja na ženinoj psihi, ilustrirajući vlastitim primjerom« (S. 6).

Također življenje duhovnosti u okolini je vidljivo svjedočenje vjere vlastitim djelima, osobito zauzimanjem za obespravljene. »Tako i vjera, ako nema djela, mrtva je u samoj sebi« (Jak 2, 20). Važnost autentičnosti i transparentnosti življene vjere po djelima u svakodnevnom okruženju susrećemo i kod drugih autora. ${ }^{55}$

\subsection{Krize na duhovnom putu hoda obitelji u riziku}

Tablica 5. Nadređene i podređene teme krize na duhovnom putu hoda obitelji u riziku

\begin{tabular}{|l|l|}
\hline Nadređene teme: & Podređene teme \\
\hline \multirow{5}{*}{ Kriza vjere } & $\begin{array}{l}\text { Propitkivanje o Božjoj prisutnosti } \\
\text { Propitkivanje o Božjem vodstvu } \\
\text { Sumnje u Božju ljubav } \\
\text { Unutarnja borba } \\
\text { Tjeskoba } \\
\text { Sumnja u Božju opstojnost } \\
\text { Raskorak između logičkog zaključivanja i vjere }\end{array}$ \\
\hline Kriza identiteta & Brige u svakodnevnici suočavanja s problemskom situacijom u obitelji \\
& Nebrojeni upitnici \\
& Nepostojanje empatije \\
& Nemogućnost praštanja \\
& Tupost \\
& Nedostatak radosti u svakodnevnici življenja \\
\hline
\end{tabular}

\footnotetext{
${ }^{55}$ Usp. Shekhar SAXENA, A cross-cultural study of spirituality, religion, and personal beliefs as components of quality of life, Social Science and Medicine, 62 (2006) 6, 1486-1497.
} 
Krize na duhovnom putu obitelji su neizbježne i prisutne te osobito dolaze do izražaja uslijed stanovitih obiteljskih rizika kada se članovi obitelji intenzivnije i dublje propitkuju o smislu, težini bolesti ili drugih obiteljskih problema i tragaju za odgovorima. ${ }^{56}$ Sve te krize čini se opravdano smjestiti pod dvije nadređene teme, a to su kriza vjere i kriza identiteta.

»Sjedila sam tako toga dana, otprilike dva mjeseca nakon postavljanja dijagnoze, u crkvi svete Mati Slobode na Jarunu. Sjedila sam Gospi pod nogama, glave zarivene u koljena, plačući, cijelu misu. Nisam znala na koju se stranu okrenuti? Gdje zatražiti pomoć? Kod gospođe koja se bavi karmom, energijama i koja je pobijedila istu dijagnozu, ili se okrenuti molitvi i samo Crkvi. Ali, ta istina koju sam vidjela i na drugoj strani!... Stalno mi se vraćalo to iskustvo što mi je ustvari stvaralo dodatan nemir. Plakala sam tako Gospi pod nogama, ne mogavši više! 'Pomozi mi, Majčice!'... - bilo je jedino što sam mogla misliti. A onda su mi u jednom trenutku mislima proletjele slike mene kao djevojčice i svih onih divnih stvari u kojima sam sudjelovala kao dijete, a koje su se događale pod okriljem Gospodnjim u njegovoj Crkvi. A najvažnije - osjetila sam opet onu zaštićenost koju sam tada kao dijete osjećala. I rekla sam: 'Ja ne znam kako, od kuda krenuti i kako hoditi, ali znam da se želim opet osjećati onako kako se mala Marijana osjećala u tvome domu, Gospodine, i zato - zatvaram vrata svemu ovome što proučavam, o čemu čitam, slušam već više godina. A u čemu nema tebe, Isuse. Zatvaram vrata svemu! Neću ostati priklonjena niti jednom učenju, niti jednoj spoznaji, iako to znači okretanje leđa samoj sebi koju sam gradila zadnje desetljeće i više. A kamo me to dovelo? Nadomak smrti. Zatvaram vrata svemu, Gospodine, a ti me vodi dalje, onako kako samo ti znaš!'... Toga dana je Gospa, naša nebeska Majčica pod čijim nogama sam plakala, spustila na mene svoj plašt ljubavi, zaogrnula me, pokazala mi gdje je Istina time postala moja zaštita, zagovornica i suputnica. Blagoslovljena bila, ljubljena moja Majčice! Srce će ti zauvijek klicati: 'Hvala!' Toga dana se dogodilo moje novo rođenje« (S. 9).

Sudionici krizu opisuju kao opće stanje tuposti, rezigniranosti i odsutnost empatije. To potvrđuje i sljedeći iskaz:

»Prvi signal, alarm, da nešto nije u redu bilo je odsustvo empatije koja je oduvijek bila moja osobina. Voljela sam ljude, bila spremna pomoći, bezrezervno opraštala, iako su mi znali govoriti da sam glupa i naivna jer sam toliko dobra. To me u mladosti nije opterećivalo jer je moje srce govorilo da to tako treba, da je prirodno voljeti i opraštati. A onda se srce 'okamenjelo'... Više me nisu pogađale tuđe nesreće. Više nisam imala potrebu pomagati, ni materijalno ni ikako drugačije. Kad bih čula da je nekome teško zbog bilo kojeg razloga, odmahnula bih rukom rekavši: 'Ih, kao da je meni lako.' Nestalo je empatije, nestalo je radosti. Dugo, dugo nisam osjetila radost. Godinama! Bila je tu, naravno, radost zbog djece, nečega u obitelji, ali radost više nije bila moje stanje duha. Izgubila sam onu radost koju osjećaš jednostavno zbog toga što - jesam! Radost zbog postojanja, zbog trenutka, bivstva. A to je tako važno osjećati!«

\footnotetext{
${ }^{56}$ Usp. Nikola DOGAN, Ludost križa - Teologija mučeništva, Crkva u svijetu, 41 (2006) 4, 443466.
} 
Životne krize su čin svjedočenja vlastitim životom, čin kršćaninove egzistencije koja je u svojim najdubljim korijenima »sudjelovanje u Kristovoj patnji«.57

»Na pitanje o Božjoj biti kršćanska teologija dala je mnogo odgovora. Ali, između mnogih, ona je jednom odgovoru dala bezuvjetno prvenstvo: Bog je ljubav. Zato se ne treba pozivati samo na neku novozavjetnu rečenicu, nego na jedan događaj: na Isusovu smrt i Isusovo uskrsnuće od mrtvih snagom Boga. « ${ }^{58}$

Stoga je jasno da osobe koje slijede kršćanski nauk i njime se nadahnjuju u svakodnevnom životu nailaze na propitkivanje, traženje vlastitog identiteta i različitih kriza, dok ne dođu ponovno do spoznaje i odgovora u Kristovoj patnji na križu i njegovom bezuvjetnom darivanju čovjeku.

\subsection{Predispozicije za učinkovito djelovanje duhovnosti}

Tablica 6: Nadređene i podređene teme kao predispozicije učinkovitog djelovanja duhovnosti

\begin{tabular}{|l|l|}
\hline Nadređene teme: & Podređene teme \\
\hline Vjerski život u obitelji & $\begin{array}{l}\text { Vjernička obitelj - redovito prakticiranje vjerskih praksi } \\
\text { Tradicionalno djeca primaju krštenje } \\
\text { Tradicionalno kršćanska obitelj } \\
\text { Prigodno odlaženje u crkvu } \\
\text { Razvijanje duhovnosti u najranijim godinama razvoja djeteta } \\
\text { Važnost roditeljskog duhovnog odgoja } \\
\text { Važnost odrastanja u vjeri }\end{array}$ \\
\hline $\begin{array}{l}\text { Aktivna uključenost u } \\
\text { svoju duhovnu zajednicu }\end{array}$ & $\begin{array}{l}\text { Duhovna zajednica - drugi dom - osjećaj privrženosti } \\
\text { Zaduženja i aktivnosti u vjerskoj zajednici } \\
\text { Djeca odlaze na vjeronauk u školi }\end{array}$ \\
\hline $\begin{array}{l}\text { Stresne obiteljske } \\
\text { situacije }\end{array}$ & $\begin{array}{l}\text { Traženje Boga } \\
\text { U teškim i neizdrživim situacijama sjetim se da Bog postoji } \\
\text { Muž s krunicom oko vrata u duhu tradicije } \\
\text { Zaduženja i aktivnosti u vjerskoj zajednici }\end{array}$ \\
\hline
\end{tabular}

Koje su to dobre predispozicije za duhovnost kao element otpornosti u obiteljskim problemskim situacijama moguće je uočiti u tablici 7. Tri su nadređene teme: duhovno ozračje obitelji, aktivnosti u duhovnoj zajednici i stresne i bezizlazne obiteljske situacije koje upućuju na Boga.

»Odrasla sam u katoličkoj vjerničkoj obitelji. Kad kažem 'vjerničkoj' mislim na redovito prakticiranje vjere. Redovita nedjeljna misa bila je neizostavan dio našeg tjedna. Ne sjećam se baš zajedničkih molitvi u obitelji, osim molitvi prije obroka i spavanja, ali na inicijativu našeg tadašnjeg župnika mi djeca smo bili toliko angažirani u crkvenim aktivnostima i raznim zaduženjima, tako da smo

\footnotetext{
${ }^{57}$ Karl RAHNER, Eucharistie und Leiden, u: K. Rahner, Schriften zur Theologie, sv. 3, Zur Theologie des geistlichen Lebens, Einsiedeln, Benzinger, 1967, 195.

${ }^{58}$ Eberhard JÜNGEL, Gott als Geheimnis der Welt. Zur Begründung der Theologie des Gekreuzigten im Streit zwischen Theismus und Atheismus, Tübingen, Mohr, 1977, 430.
} 
puno puta tijekom tjedna sudjelovali i u dnevnim misama ili molitvama svete krunice. Pjevali smo u dječjem crkvenom zboru, sudjelovali u vjeronaučnim olimpijadama, uređivali crkvu s časnim sestrama, izrađivali s njima cvjetne aranžmane za Sve svete, a ja sam čak i vrlo često svirala orgulje tijekom nedjeljnog bogoslužja ili čitala u službi riječi. Bilo je tu još puno toga. Crkva je bila naš drugi dom i tamo smo se osjećali sigurno i zaštićeno. Pišem sve ovo jer će mi upravo taj osjećaj zaštićenosti jednoga dana, kako ja kažem, 'spasiti život'« (S. 5).

Važno je usvajanje i njegovanje tradicije za razvijanje duhovnosti. Na to upućuje i brojna literatura: Poticanje duhovnog razvitka i iskustva djeteta nije lak zadatak i sudionici u tom procesu često imaju poteškoća, ali je vjera djece i njihova priprema za zrelije vjerovanje važna roditeljima koji drže do duhovnih vrijednosti. Važno je da roditelji budu dosljedni, pouzdani i odgovorni. Da bi imali što bolji mogući duhovni utjecaj na djecu, trebali bi dijeliti s njima duhovna iskustva i odgovarati na njihova pitanja. ${ }^{59}$ Osim posebnog vremena posvećena duhovnoj izobrazbi, važne su roditeljske svakodnevne kućne rutine i prakse putem kojih naglašavamo važnost Boga u životu i ljepotu, čime se djeca inspiriraju. Važnost različitih religijskih rituala ${ }^{60}$ stvara u djeci u najranijoj dobi pozitivno ozračje za razvijanje duhovnosti. Vjerske poduke u školi i župnoj zajednici u komplementarnome su odnosu jer djeci omogućavaju višestruko upoznavanje religije te vode duhovnom rastu i razvoju djece. Duhovnost je proces i ona raste i razvija se pod utjecajem različitih čimbenika. ${ }^{61}$

»Važno je, ooo itekako je važno odrastanje u vjeri! Djetinjstvo ostane 'zapisano' u duši čovjeka, možda kao najvažnije razdoblje života. Ono nas formira, usmjerava, gradi. Ono usađuje u nas vrijednosti koje poslije razvijamo, njegujemo i na temelju kojih gradimo sebe, svoj život, utječući tako ne samo na vlastiti, već i na živote ljudi koji čine našu obitelj« (S. 5).

Odrastanje u duhovnom ozračju i tradiciji ima velik utjecaj na duhovni profil osobe. No neka istraživanja pokazuju da i u slučaju bezizlazne situacije, na koje čovjek ne može utjecati niti je može tumačiti, takva osoba poseže za traženjem Boga i traži njegovu pomoć.

\footnotetext{
${ }^{59}$ Usp. Donald RATCIFF, Experiencing God and Spirtual Growth With Your Child, (2008), http://childsprirituality.org./experience/ (05.10.2016).

${ }^{60}$ Usp. Emily HUFTON, Parting Gifts. The Spiritual Needs of Children, Journal of Child Health Care, 10 (2006) 3, 240-250.

${ }^{61}$ Usp. Zdravka LEUTAR, Uloga socijalne mreže u razvoju duhovnosti djece - kršćanska perspektiva, Dijete i društvo, 8 (2006) 2, 461-475.
} 


\subsection{Duhovnost kao resurs snage i otpornosti koji je uvijek moguć}

Tablica 7. Nadređene i podređene teme duhovnosti kao resursa koji je uvijek moguć

\begin{tabular}{|l|l|}
\hline Nadređene teme: & Podređene teme \\
\hline $\begin{array}{l}\text { Duhovnost kao izraz darovane ljubavi } \\
\text { Stvoritelja }\end{array}$ & $\begin{array}{l}\text { Djelovanje duhovnosti bez predispozicija } \\
\text { Duhovnost je uvijek moguća } \\
\text { Duhovnost kao zahvat Stvoritelja }\end{array}$ \\
\hline $\begin{array}{l}\text { Traženje smisla u obiteljskim kriznim } \\
\text { situacijama }\end{array}$ & $\begin{array}{l}\text { Bezizlaznost situacije } \\
\text { Vlastita bespomoćnost } \\
\text { Smisao u kršćanstvu i Kristovu križu }\end{array}$ \\
\hline
\end{tabular}

U tablici 7 sudionici izražavaju duhovnost uvijek moguću i bez predispozicija koje smo prije spominjali. Naravno, literatura naglašava važnost odgoja u vjeri koja postaje snažan resurs za život djeteta, ${ }^{62}$ ali je duhovnost moguća kao resurs i kroz potragu za smislom obiteljskih kriznih situacija, kad se članovi propitkuju i osjećaju da se ne mogu s njima nositi:

»Bog nas ne ostavlja u ovoj smrti nego koristi krizu djece koja su u pubertetu da bi se mi kao roditelji nanovo zbližili. Potpuno nemoćni pred pitanjem što učiniti i kako 'popraviti' stvari, zavapimo Bogu« (S. 5).

Osjećaj vlastite bespomoćnosti i nadilaženje djelovanja, nemogućnost da si osoba može pomoći, usmjerava je k transcendentalnim promišljanjima:

»Nama kao roditeljima vjera je dala snagu za vlastiti život i brak, nadu da ćemo ipak na vrijeme stići posvjedočiti je i svojoj djeci i popraviti učinjenu štetu iz doba kada smo se oholili i oslanjali na svoju pamet. Naučili smo ne gubiti ovu nadu, ne padati u očaj i vjerovati da će Bog, po zagovoru svoje majke Marije i svih svetih, nadoknaditi našoj djeci za sve propuste koje smo činili... Njemu je sve moguće. Za obraćenje nikada nije kasno« (S. 6).

Važnost spoznaje koju osoba prepozna u trenutcima traženja i propitkivanja jest element koji je čini otvorenom da zaista u vjeri i nadi gleda $u$ pozitivan ishod. ${ }^{63}$ Iskustvo životnih kriza i oslanjanje na Stvoritelja u teškim životnim situacijama, sudionike ovog istraživanja dovodi do duhovnog iskustva koje se manifestira u konkretnim promjenama života i u unapređenju obiteljskih odnosa. Navedena duhovna iskustva jačaju, proširuju te definiraju način na koji pojedinac gleda na sebe, na vlastiti smisao i na svoju ulogu u životu. ${ }^{64}$ Takvo iskustvo potvrđuje i istraživanje provedeno u karizmatskim zajednicama. ${ }^{65}$

»E da sam to čula barem koju godinu prije! Možda bi patnja bila manja. Možda. Ali opet, po križu smo mu tako slični. Po križu barem na trenutak postajem

\footnotetext{
${ }^{62}$ Usp. isto.

${ }^{63}$ Usp. Schneider, Mannell, nav. dj., 3-24.

${ }^{64}$ Usp. Juliet ROTHMAN, Spirituality. What we can teach and how we can teach It, Journal of Religion and Spirituality in Social Work, 28 (2008) 1, 161-184.

${ }^{65}$ Usp. Dučkić, Blažeka Kokorić, nav. dj., 425-452.
} 
slična Isusu. A to je ono čemu težim cijeli život. Biti u njegovoj prisutnosti. No, to treba osjetiti srcem, a ne umom, a za to je potrebno vremena i trpljenja...« (S. $5)$.

Zapravo, promatranje duhovnosti koja se događa u životu sudionika ovog istraživanja upućuje da nema određenih pravila. Neke predispozicije rasta i hoda u vjeri pomažu da se lakše koristi i primjenjuje duhovnost u obiteljskim situacijama, ali ona je moguća i može biti isključivo darovana u trenucima krize te iz nje može proizaći transformiran život osobe tijekom daljnjeg života, što ima pozitivne učinke u obiteljskoj kohezivnosti i odgoju djece te u interakcijama s okolinom. Ojačana osoba kroz duhovnost može promatrati životne krize kao sastavni dio svog kršćanskog hoda pa uzor i ideal suočavanja i nošenja s krizom vidi u svome uzoru Isusu Kristu. Takva kriza onda izgrađuje, tvrde sudionici ovog istraživanja.

\section{Zaključak}

Na temelju analize i sinteze promatranog istraživanja te konzultiranja svjetske i domaće literature čini se opravdanim zaključiti da prakticiranje duhovnosti može biti snažan resurs snage i otpornosti obitelji u rizičnim okolnostima. Dobivena su sljedeća tematska područja djelovanja duhovnosti:

- Za svaki obiteljski rizik duhovnost je moguća kao resurs otpornosti: za slučaj bolesti, starosti i starenja, invaliditeta, narušenih bračnih i obiteljskih odnosa, siromaštva u obitelji, smrti u obitelji i promjena koje rezultiraju ranjivošću odnosa.

- Izvori snage u duhovnosti za obitelj su brojni: spoznaja vrednota vjere, nade i ljubavi, molitva, Božja Riječ, pripadnost duhovnoj zajednici, sakramenti, osobito euharistija i ispovijed, duhovno vodstvo (savjetovanje), različita duhovna literatura, seminari, predavanja, hodočašća, zajedništvo kao sredstvo podrške članovima, permanentna duhovna edukacija, obnavljanje u duhovnosti i prakticiranje duhovnosti u obitelji.

- Dobrobiti za obitelji u riziku su višestruke: unutarnja sloboda i sigurnost članova obitelji, praštanje, obiteljska kohezivnost, jačanje i rast u vjeri članova obitelji, rad na sebi, poticaj da se ljubi iskreno.

- Autentičnost djelovanja duhovnosti u obitelji se očituje u iskrenom i potpunom življenju obiteljskih uloga, Krist postaje najveći uzor u svakodnevnici življenja članova obitelji na svim razinama, a življenje duhovnosti na djelu, poticaj je drugim članovima obitelji i da sve činimo iz ljubavi, ne iz dužnosti. 
- Krize na duhovnom putu hoda obitelji su ove: krize vjere, identiteta, pripadnosti vjerskoj zajednici, propitkivanje o smislu, propitkivanja o Bogu, ljubavi Boga i čovjeka, smislu patnje. Trenuci odsutnosti, empatije, praštanja i tuposti su dragocjeni u životu članova obitelji jer služe kao sredstvo rasta i sazrijevanja osobnosti te produbljivanja vjere.

- Predispozicije za učinkovito djelovanje duhovnosti u obiteljskim rizicima su: njegovanje duhovnosti kod djece od najranije dobi života djeteta, prakticiranje vjerskih praksi u obitelji, aktivno sudjelovanje u svojoj duhovnoj zajednici, važnost duhovne dimenzije roditelja, važnost spoznaje da je Bog ljubav. Njegovanje tradicije može biti dobra predispozicija za praktično življenje duhovnosti.

- Spoznaja da su milost i vjera, kao nezasluženi Božji dar, mogući i bez svih navedenih preduvjeta da obitelj praktično živi duhovnost i da ona bude resurs snage njezinim članovima u rizičnim okolnostima.

- Obiteljske krizne situacije mogu pokrenuti promjene u obitelji te usmjeriti članove obitelji da iziđu jači i obogaćeni novim iskustvom. Kreativno rješenje obitelji u riziku može biti u tome da se članovi obitelji usredotoče na bitno. Treba »otpustiti« nebitno i prepustiti se vodstvu - nije moguće ići sam, treba priznati ograničenost i osloniti se na »nešto više«. 


\section{Ivan Leutar* - Zdravka Leutar** \\ Spirituality as a resource of power and resilience of families in risk circum- stances}

\section{Summary}

Spirituality is defined as the need to find the end of meaning and purpose in life and a desire to live an integrated life. Studies have shown that religious families, in relation to those who are not, have a higher level of faith and hope of a good outcome during periods of insecurity, uncertainty and stress. Also, their members are less likely to express certain social pathologies. The aim of this Paper is to get an insight into participants' perception of spirituality as a means of dealing with high-risk conditions in the family, so the research question was about the experience of participants who practice spiritual life on the role of spirituality in facing risks in the family. Participants were persons who find spirituality important in their life and draw strength from it for life's challenges. There were 12 participants, both sexes, aged 33-57, all highly educated. For data collection, a qualitative approach was used and a method of semi-structured interviews. For data analysis, thematic analysis was used. The following results were obtained: Spirituality is a possible resource of empowerment of family members' at all family risks. Spirituality as a source of power is possible when faith, hope and love are recognized as true life values and accompanied by spiritual practices such as prayer, reading the Word of God and the sacraments as special resources to cope with difficult family situations, as well as fostering unity, permanent education in spirituality and sustained growth in spirituality. The importance of authentic spirituality of life that is manifested in concrete actions in the family and the environment. The crises that occur in the spiritual life are associated with crises of faith and identity and serve as a means of strengthening and transformation of the very person and family members. To use spirituality as a resource of resilience, it is important to have predispositions in terms of religious education of family members, nurturing spirituality from an early age, but it was also recognized that spirituality can be detected as an empowering resource not before a crisis and can serve as a means of transformation of family life.

Keywords: spirituality, family resilience, family at risk, sources of power, the welfare of spirituality, authenticity, crisis of faith and identity, faith, hope and love.

(na engl. prev. Ivana Krencer)

\footnotetext{
* Ivan Leutar, PhD, Assistant Professor; Faculty of Humanities and Social Sciences, Matice Hrvatske bb, 88000 Mostar, Bosnia and Herzegovina; E-mail: ileutar@vodafone.de.

**Zdravka Leutar, PhD, Full Professor; Law Faculty of University of Zagreb; Department of Social work; Nazorva 51, HR-10000 Zagreb, Croatia; E-mail: zleutar@pravo.hr.
} 